\title{
UNIVERSITYOF
}

FORWARD

THINKING

WESTMINSTER用

WestminsterResearch

http://www.westminster.ac.uk/westminsterresearch

\section{Strategic brand alliances: Research advances and practical applications}

Singh, J., Quamina, L. and Stavros, K.

This is an accepted manuscript of a book chapter published by Routledge in The Routledge Companion to Contemporary Brand Management on 13 July 2016, available online:

http://www.routledge.com/9780415747905

The WestminsterResearch online digital archive at the University of Westminster aims to make the research output of the University available to a wider audience. Copyright and Moral Rights remain with the authors and/or copyright owners.

Whilst further distribution of specific materials from within this archive is forbidden, you may freely distribute the URL of WestminsterResearch: ((http://westminsterresearch.wmin.ac.uk/).

In case of abuse or copyright appearing without permission e-mail repository@westminster.ac.uk 


\title{
Chapter 9
}

\section{STRATEGIC BRAND ALLIANCES: RESEARCH ADVANCES AND PRACTICAL APPLICATIONS}

\author{
Jaywant Singh, La Toya Quamina, Stavros P. Kalafatis
}

\section{Introduction}

Co-branding or brand alliance, refers to a wide range of co-operations between two or more brands which include Joint-sales promotions (e.g., Reebok and Pepsi), Advertising alliances (e.g., Kellogg and Tropicana), Bundling marketing (e.g., Microsoft and McAfee), Ingredient branding (e.g., Dell and Intel), Dual branding (e.g., Avis and Budget) and Product combinations (e.g., Betty Crocker and Hershey's). It is a strategic business development opportunity for brands, in which the sum of the combined brand assets is greater than the parts of the individual brands (Rao and Ruekert, 1994). Brand alliances have attracted considerable research interest over the last few years, as evidenced by the increasing number of empirical studies in various contexts published since the mid-1990s (e.g., Park, Jun and Shocker, 1996; Lafferty, Goldsmith and Hult, 2004; Helmig, Huber and Leeflang, 2008; Kalafatis, Remizova, Riley and Singh, 2012; Singh, 2015). The academic research interest in co-branding reflects a growing awareness that leveraging a firm through brand associations is more cost effective and less risky than traditional brand extension strategies (Besharat and Langan, 2014). Furthermore, it presents a fresh opportunity for strategic advantage in a fiercely competitive marketplace (Bucklin and Sengupta, 1993).

The practical implication of this area of brand management is also evident in a variety of industries such as food and drink, retailing, air travel and financial services. In the last twenty-five years, there has been an increase in the number of products introduced by two 
brands in an alliance. Notable examples include Nike and Apple's Sports Kit, Fiat and Mattel's limited edition car, and Coca-Cola and OPI's line of nail lacquers.

Beyond these examples, the proliferation of brand alliances is consistent with Austin's (2000) prediction that the twenty-first century will be the age of alliances. Data on co-branding suggests that alliances in the US have grown by $25 \%$ each year since 1987 and that 20,000 alliances were formed worldwide between 1997 and 1999 (Booz, Allen and Hamilton, 1998). In 1999, the top 2000 companies in the world reported a return on investment of $17 \%$ through strategic alliances (Booz, Allen and Hamilton, 1998). More recently, co-branded credit cards in the US alone generated $\$ 809$ billion in revenue (Report Buyer, 2014). As suggested by Kumar (2005), co-branding will be a standard practice for 98 percent of retailers.

Both academic researchers and businesses are keen to grasp the benefits surrounding cobranding, even though there is a lack of knowledge on the risks associated with the marketing strategy. The extant research points to the advantages of co-branding, such as the enhancement of customer-based brand equity (e.g., Washburn, Till and Priluck, 2004), access to new markets and economies of scale (e.g., Das and Teng, 1998), yet not all co-branded alliances are successful. Leuthesser, Kohli and Suri (2003) estimate that as many as 90 percent of alliances are unsuccessful. For example, the alliance between AT\&T and British Telecommunications (2000) failed in less than two years, amidst losses and incompatible brand vision. Other recent examples include failures by established brands such as Suzuki and Volkswagen (2011) and Hertz and Ryanair (2015). These cases demonstrate that despite the empirical evidence demonstrating the benefits of the marketing strategy, challenges and difficulties are also pervasive in co-branding. 
In the light of the above, a delineation of the different streams of literature and related factors that drive co-branding success and failures can advance the understanding of this subject area. An integrated review of the existing knowledge on co-branding will enable both researchers and managers to assess the opportunities as well as the boundaries of introducing and sustaining a co-brand alliance.

This chapter presents a state-of-the-art review of the research evidence on co-branding. This review also differentiates the various types of co-branding strategies and highlights the theoretical underpinnings of co-branding research. The chapter concludes by envisaging avenues for future research.

\section{Defining Co-Branding}

Co-branding has been extensively explored by researchers, leading to a variety of definitions and terms such as brand alliances, co-branding, co-marketing, joint-branding, and symbiotic marketing, used to refer to a broad range of cooperative brand marketing strategies (Simonin and Ruth, 1998). A well-known definition of co-branding is by Rao and Ruekert (1994) who define it as a symbolic or a physical association between two or more products. Park, Jun and Shocker (1996) define co-branding as the pairing of two or more existing brand names (constituent brands) to create a separate and unique product (composite brand). Helmig et al. (2008) suggest co-branding as a "planned long-term strategy in which one product is branded and identified simultaneously by two brands" (p. 360), suggesting that partner brands must be 1) independent before, during, and after the creation of the composite brand, 2) implement the co-branding strategy on purpose, and 3) the cooperation between the two brands must be visible to buyers. 
Notwithstanding the lack of a universal definition of co-branding, there is agreement amongst researchers that co-branding is a marketing partnership between two or more brands. (e.g., Desai and Keller, 2002; Gammoh, Voss and Chakraborty, 2006; Besharat and Langan, 2014). In today's highly competitive marketplace, building a strong brand requires finding alternative and cost effective strategies to expand a brand's portfolio. Traditional brand extension strategies involve one brand within the same company (e.g., monobranding) while co-branding includes two or more brands involving different companies. As suggested by Helmig et al. (2008): "Co-branding strategy might be more beneficial than a brand extension strategy because a second brand can contribute a perception of additional value to both the co-branded product and the primary brand itself that the primary brand cannot achieve on its own" (p. 362).

\section{Co-Branding in Practice}

A co-brand alliance can take many forms and may vary in duration. As mentioned earlier, it is commonly categorised into six types: joint-sales promotion, advertising alliance, bundling marketing, ingredient branding, dual branding, and product combinations. Table 9.1 summarises the prevalent co-brand alliance strategies with examples.

\section{Table 9.1: A comparison of the six types of co-brand alliances}

\section{Here}

A differentiating factor in the alliances listed above is the length of the partnership. Shortterm alliances such as joint-sales promotions and advertising alliances are used by marketers to "create relevance, differentiation and energy quickly in an effort that is not expected to 
have a long life" (Aaker, 2004, p. 180). Long-term alliances, on the other hand, are collaborations that result in the creation of a new product (Aaker, 2004) and are typically used to improve market position over time (Washburn et al., 2000). Notwithstanding the differences, both short-term and long-term alliances are attractive marketing strategies that offer competitive advantages that would otherwise be beyond one company's reach (Cooke and Ryan, 2000). In the section below, the extant research on these strategic advantages is discussed.

\section{The Benefits of Co-Branding}

Empirical research on the competitive advantages brands gain from co-branding can be summarised into two perspectives. The first concerns the acquisition of assets (tangible and intangible), such as access to new markets and consumers (e.g., Abbratt and Motlana, 2000) and the advantage of shared resources and competencies that follow (e.g., Bengtsson and Servais, 2005). The second perspective focuses on the maximisation of brand value such as the boost in revenue and customer-based brand equity (e.g., Besharat, 2010). The research evidence on each of the above factors is discussed below.

\section{Acquisition of Tangible and Intangible Assets}

Abbratt and Motlana (2000) demonstrate that an organisation's access to new markets is enhanced when partnered in a co-brand alliance. Analysing sales data from dairy brand Danone, the authors show co-branding as an effective strategy for brand transition in an unknown market. Specifically, the results suggest that co-branding with Clover had a positive impact on Danone's market share, which increased 9 percent in three years. By partnering with a well-known local entity, the brand enhanced its credibility and success in the South African market. Consistent with the above, Vaidyanathan and Aggarwal (2000) affirm that 
the probability of entry by an unfamiliar brand partnered with a nationally branded ingredient brand is higher when compared to the probability of entry by a new co-branded product without a nationally branded ingredient partner. Specifically, the national partner lends greater reassurance and communicates to a dubious market that the brand can be trusted. An explanation for the above is found in earlier work by Rao and Ruekert (1994) who propose that co-branding provides credible marketplace signals. When an unknown or unobservable brand partners with a highly reputable one, consumers assume that the overall quality of the product is good, because the second brand name signals confidence (Kalafatis et al., 2012).

In addition to enhancing market access, the minimisation of investment is another benefit of pursuing alliances with other brands. The financial costs associated with entering a new market are a substantial investment for brands launching a co-branded product. Costs including manufacturing, retailing and promotion can lead to the high price of the product. Lambe, Spekman and Hunt (2002), show that the presence of two brands in a co-brand alliance can combine resources in a manner that allow brands to enhance customer value with lower costs. An illustration of this is evident in dual branding agreements where brands share promotional and overhead costs. For example, KFC and Taco Bell share the same building, and in some instances the same kitchen and staff. Similarly, Costa Coffee is located in Tesco retail stores, allowing Costa to take advantage of the existing retail space, and Tesco to offer an additional service to its customers at no additional cost.

Co-branding may also have effects on the risks associated with launching a new product or service in a new market, particularly when partners have access to shared resources such as established stakeholder relationships, product distribution channels, media and knowledge capabilities. According to Blackett and Boad (1999), access to the strategic capability of a 
partner organisation is likely to reduce the risks associated with a firm entering an unknown market particularly in a new sector or unfamiliar territory. Bengtsson and Servais (2005) illustrate that co-branding can be a viable strategy for risk reduction in industrial markets. The above authors examine two Danish companies and show that co-branding made it easier for the participating firms to improve its competitive advantage by decreasing uncertainty among buyers. About $82 \%$ of buyers found that closer cooperation between brands decreased scepticism about a product. Interestingly, however, the authors found no evidence to support their hypotheses that co-branding activities could improve access to shelf/retail spaces and high turnovers. So far there is no empirical evidence to support the view that co-branding can achieve retail and distributive efficiencies to leverage an organisation's sales. The above represents an area for future research which can examine whether co-branding can offer organisations better distributive channels than a single branded strategy. Evidence related to the subject of high turnovers is discussed below.

\section{Maximisation of Brand Value}

Research has also found that co-branding has an effect on revenue generation and cost benefits. In contrast to Bengtsson and Servais’ (2005) finding, Erevelles, Stevenson, Srinivasan and Fukawa (2008) suggest that by reducing the probability of entry by competitors, both the manufacturer and supplier brands in a co-brand alliance can benefit from cost benefits. As illustrated in the study, supplier brands enter into partnerships with manufacturers in a bid to reduce competitive entry. In turn, suppliers reward manufacturers with lower prices which may be passed down to the consumer. The authors find that supplier's profit is likely to be higher with co-branding than without it. Similarly, Kanter (1994) notes that lower manufacturing costs can translate to long-term customers and economies of scale, which can likely lead to increased revenue for the partner brands. 
Moreover, it is believed that long-term consumers build affective commitment and brand loyalty (Fullerton, 2003). Brand loyalty is likely to translate into repeat purchases and stable customer lifetime values, which present further cost-benefits for brands (Oliver, 1999). In a study examining the behavioural impact of a co-branded product across segments of consumers with varying levels of brand commitment or loyalty, Swaminathan and Reddy (2012) show that co-branding can enhance brand sales and overall market share without the risk of cannibalising own brand sales. Further, Erevelles et al. (2008) suggest that co-brand alliances with advertising support can enhance the marketing and promotion of the product in the business-to-business context. Such support is likely to increase product awareness, which can lead to an increase in consumer demand and high turnover. Overall, empirical research to support the view that brand alliances translate to high turnover is limited. Future research could examine the financial impact of co-branding on organisational efficiencies.

Empirical research has shown a critical advantage of co-branding in its ability to increase a brand's equity, and as a result, strengthen its competitive position in the marketplace. From the viewpoint of the organisation, brand equity is a critical asset for any business. As suggested by Aaker (1991), a company with a strong brand equity can be leveraged to enhance brand loyalty and increase sales. Studies in a variety of sectors show that cobranding can maximise brand value by increasing the customer-based brand equity (CBBE) of the constituent brands in the alliance (e.g., Washburn et al., 2004; Guillet and Tasci, 2010; Ueltschy and Laroche, 2011). For example, Kalafatis et al. (2012) demonstrate that brands with equivalent equity levels share the benefits of the co-branding equally, while lower equity brands benefit more from the alliance than higher equity partners. Moreover, the research literature suggests that an alliance paired with a high-equity and low-equity brand can be 
potentially dangerous for the high-equity partner. For example, Lebar et al. (2005) show that established brands have a higher risk of losing their brand esteem by partnering with an unfamiliar partner. The above is further supported by Van Osselaer and Alba (2000), who demonstrate that the value of a high-equity brand in a high/low alliance can lead to dramatic reduction of the brand's subsequent predictive quality. In other words, a low-equity brand may serve as a discounting cue for a high-equity brand, which may have an impact on consumers' future evaluations of the well-established brand.

Conversely, Washburn et al. (2000) find that although low-equity brands may benefit most from co-branding, high-equity brands are not depreciated even when paired with a low-equity partner. A key factor likely to alter the equity ratings of the high-equity brand in this context lies with the consumer's first usage experience with a brand (referred to as product trial). The authors show that positive product trial increases brand equity for all co-branded combinations (high/high, low/low and high/low). The above assertion is supported by Leuthesser et al. (2003) who affirm that "well-respected, powerful brands have relatively little to lose in co-branding ventures, even when the partner brand is a weak one" (p.39). Overall, the above evidence suggests that co-branding with a high-equity brand is an attractive strategy for a low-equity brand.

Altogether, co-branding is an alternative brand expansion strategy that can offer benefits to an organisation. For instance, it can help an unfamiliar brand gain access to a new market, minimise start-up and running investment, increase sales and enhance CBBE. However, further empirical research is needed to examine the assertions that two brands harnessed together can translate into quicker returns, price premiums, access to leading edge technology and reinforced advertising messages (Blackett and Boad, 1999). If co-branding is to be a 
viable alternative for brand expansion as suggested in prior research, additional empirical work is warranted across different product categories and markets to establish further strategic benefits.

A discussion of the existing evidence corroborating the advantages of co-branding needs to be seen in the light of inherent risks. For instance, the said benefits created by a partner having access to resources and intellectual property of the other, can also undermine an organisation and expose them to the risk of lookalikes or takeovers. Whether the advantages of co-branding outweigh the risks or vice versa are less important. The risks of co-branding are discussed below.

\section{Risks of Co-Branding}

The preceding discussion on the benefits of co-branding has shown that where two brands are presented in the context of each other, associations and values embodied by each brand can be transferred to the other. Employed effectively, this transfer of effect represents a win-win opportunity for partner brands. However, co-branding is not without risks. The reason most co-branding alliances fail (e.g., Day, 1995; Leuthesser et al., 2003) may be due to unique risks inherent in co-branding such as differences in strategic visions, legal and financial disagreements or incompatible brand synergies (Blackett and Boad, 1999). A review of the literature reveals a paucity of empirical studies that explore the risks and pitfalls of cobranding. So far only four studies have examined the transfer of negative spill over effect in co-branding (e.g., Till and Shimp, 1998; James, 2005; Votolato and Unnava, 2006; Suh and Park, 2009). Negative spill over explains the undesirable changes in consumers' attitudes that a brand suffers when it experiences an unexpected negative event, as discussed below. 


\section{Transfer of Negative Spill over Effect}

The benefits of co-brand alliances are sometimes tempered by undesirable brand events that cause a partner brand to receive negative publicity. For example, Accenture and Nike were affected by the controversy surrounding Tiger Woods. Ford received negative media attention and boycotted in the wake of Firestone's tyre scandal and more recently, National Football League (NFL) received backlash from supporters amidst the Ray Rice domestic abuse controversy. Such amplified effect of negative events is explained by the well-established notion suggesting that negative information weighs heavily in evaluations due to an inherent cognitive bias known as Negativity Effect (e.g., Fiske 1980; Ito, Larsen, Smith and Cacioppo, 1998).

Despite the prevalence of brand-related negative events (Ahluwalia, Burnkrant and Unnava, 2000) and related psychology literature supporting the view that bad is stronger than good (e.g., Baumeister, Bratslavsky and Finkenauer, 2001), so far only four studies have examined how a negative event involving one partner can have a knock-on effect to the other partner (e.g., Till and Shimp, 1998; James, 2005; Votolato and Unnava, 2006; Suh and Park, 2009). These studies show that co-brand alliances are sensitive to brand crises. For example, Till and Shimp (1998) show that given a sufficiently strong associative link between a celebrity endorser and a brand (a form of dual branding co-branding), negative information about the celebrity can cause risk to the partner brand's reputation. When consumers' perceptions of a celebrity are negative following bad publicity, their evaluation of the organisation is even more negative. Similarly, Votolato and Unnava (2006) find negative spill over from the partner brand to the host brand only occur when the host brand is viewed as equally culpable for the offence. When the host brand is linked directly to the competence failure of an organisation, consumers are likely to transfer this negative association to the other brand in 
the alliance. As Weber and Sparks (2004) illustrate, a failure involving a partner brand can have undesirable effects on the host brand via negative evaluations, which leads to customer dissatisfaction, negative word-of-mouth and ultimately reduced brand loyalty.

In addition to the risk to a partner's reputation, negative spill over that occur during an alliance may be rehearsed and passed on in a subsequent product or alliance of the partner brands. As shown by Suh and Park (2009), when a favourable host brand introduces its own product after an alliance with a high-credibility partner brand, negative cognitive responses are activated, resulting in low acceptance of the host brand's new product launched after the brand alliance is terminated.

Although the above examples demonstrate evidence on negative spill over in co-branding, these studies do not go beyond capturing the impact of negative events on the partner brands. The literature is silent on whether negative spill over in a partner brand is likely to transfer to the co-branded product. Moreover, very little is known about how the failure to meet objectives, incompatible brand values, partner repositioning and other financial and legal issues, could attribute to unsuccessful co-branding partnerships (Blackett and Boad, 1999). Table 9.2 below illustrates some failed alliances over the years.

Table 9.2: Examples of unsuccessful co-brand alliances 
The above examples suggest that marketers still require empirical knowledge about the risks associated with co-branding. Further research is warranted to comprehend the factors associated with co-branding failures.

\section{Conditions for Successful Co-Branding}

Several studies have suggested that for an alliance to be successful four factors must be considered, 1) attitudes toward the partner brands, 2) familiarity of the partners, 3) the complementarity between the product categories, and 4) the brand fit between the partners. Product fit refers to the extent to which two product categories are compatible. Brand fit refers to the consistency of the partners brand image and personality.

Park et al. (1996) hypothesised that brand alliances are evaluated more favourably when the partner brands are complementary. The authors demonstrate that when the salience and performance levels of the brands match, consumers exhibit greater assurance about the product. The presence of the two complementary brands is viewed more positively than an alliance consisting of two highly favourable brands that are not complementary to each other. Similar effects were found by Simonin and Ruth (1998) who found that the fit between the images of participating brands has a positive influence on co-branding evaluations.

Specifically, the authors show that brand fit, in particular, has the highest impact on the evaluation of co-branded products. Helmig, Alexander and Leeflang (2007), however, found that product fit has the strongest influence on consumers' behavioural intentions. Further, the study shows that product fit positively influences brand fit. As the authors point out, if two product categories fit well together, brands closely associated with these product categories are also likely to be perceived as having high fit due to strong awareness. Thus, brand and 
product fit not only impact attitude towards the co-branded product, but product fit significantly influences brand fit as well.

Baumgarth (2004) argues that both factors; brand fit and product fit are the most important success factors in a co-brand alliance. The above assertion is supported by Lanseng and Olsen (2012) who show that both brand consistency and product category fit influence consumers' evaluations. Notably however, the authors state that the latter is only important in brand alliances that satisfy consumers' functional need (e.g., Crest and Scope). For symbolic brand alliances (e.g., Mercedes-Benz and Swatch) that appeal to consumers' desires for selffulfilment, product fit is not important in evaluating the alliance. Overall while the debate on whether product or brand fit is more influential on co-brand evaluation varies, it is clear that both degrees of fit between partners play a pivotal role in consumers' acceptance of the alliance. A lack of fit between the brand image and products of partners can lead to the conclusion that the alliance is meaningless (Bouten, Snelders and Hultink, 2011). Regarding familiarity, Simonin and Ruth (1998) demonstrate the role of brand awareness in the transfer of affect from one brand to another. The authors show that the more familiar consumers are with the partners in an alliance, the greater the strength of relations are between the co-brands. This finding is supported by Levin and Levin (2000) who demonstrate assimilation effects in the evaluation of dual branding alliances. The authors find that when the target brand is less familiar than the context brand, transfer of effect moves from the familiar to the unknown brand. In a seminal work in B2B markets, Kalafatis, Riley and Singh (2014) show that assimilation is more evident when the highly familiar brand has positive valence, that is, positive brand information is likely to have a greater significant effect on the meaning transfer between high and low familiar brands. 
Despite these and other studies that predicate that the presence of a high familiar brand can improve consumers' assessments of an unknown focal brand (e.g., Voss and Gammoh, 2004; Bluemelhuber, Carter and Lambe, 2007), familiarity tends to have a lesser impact on cobranding evaluations (Baumgarth, 2004). Linking a more familiar brand with a less familiar one is not guaranteed to influence consumers' perceptions of the co-branded product as shown by Guillet and Tasci (2010). In a quasi-experiment on the transfer effect of cobranding on CBBE of hospitality products, the authors show that while high familiarity did affect consumers' evaluations of the composite brand, it did not guarantee co-branding success.

In addition to fit and familiarity, a number of studies demonstrate that positive pre-attitudes toward the constitute brands is an important factor in determining the success of a cobranding alliance and intention to purchase (e.g., Baumgarth, 2004; Rodrigue and Biswas, 2004; Singh, 2015). In a dissertorial study, Musante (2000) demonstrates that brand attitude concerning brand image and favourability can significantly impact consumer's evaluation of co-brand alliances. Specifically, the author shows that associating one brand with a partner that is perceived high on a certain image trait can increase consumer's positive evaluation of the alliance. The finding underscores an important point, that is, judgement about an alliance is likely to be affected by the context cues of the partner brands. A brand is presented in the context of another, such that the potential for the transfer of positive and negative association is always present.

In sum, the extant research establishes that attitude towards co-branding are enhanced when one of the brands in the alliance is highly familiar to consumers, when product and brand fit 
are high, and when consumers' prior attitudes toward the partner brands are positive. Future studies can account for other contributory factors that lead to positive cobrand evaluations.

\section{Theoretical Underpinnings of Co-Branding Research}

Extant co-branding literature identifies various theories used to explain the transfer effect that follows from one partner to another and how it impacts co-branding initiatives. In particular, Signaling theory (Spence, 1973), Information integration theory (Anderson 1981), Associative network theory (Anderson, 1983) and Attitude accessibility theory (Fazio, Powell and Williams, 1989) are the theoretical bases identified in extant co-branding studies.

Information integration theory proposed by Anderson (1981) suggests that attitudes are formed and changed through the integration of new information with existing attitudes, beliefs or perceptions. According to Simonin and Ruth (1998): “...judgments about the brand alliance are likely to be affected by prior attitudes toward each brand, and subsequent judgments about each brand are likely to be affected by the context of the other brand." (p. 32). The theory holds that a major consideration for the effectiveness of co-branding is congruency. When two brands are paired, the features of an organisation, such as an unfavourable brand image are likely to become diagnostic of the other. Some of the key studies employing the above theory are Washburn et al. (2000), Mazodier and Merunka (2012) and Singh (2015), amongst others.

Similarly, the Associative network theory by Anderson (1983) theorises that memory consists of individual pieces of information called nodes, which are recalled from memory when stimulated. According to the theory, transfer effect occurs when one set of nodes (e.g., memory about an event such as the UEFA Champions League) prompts thinking about other 
'linked' nodes (e.g., Heineken the competition's sponsor). A fundamental condition of the associative network is the conditioning that the stimulus and response occur together. For example, a consumer will only be able to associate the stimuli about one brand to another if the alliance is continuously reinforced through ads, public endorsements etc. Examples of cobranding studies employing this theory are Balachander and Ghose (2003), James (2005), and Kalafatis, Ledden, Riley and Singh (2016).

A prominent theory in the co-branding domain, Signaling theory proposes that people rely on signals as perceivable indicators of things they cannot observe directly (Spence, 1973). The signaling theory has been used in co-branding as a quality cue when information about a partner brand is either unobservable or not available. As suggested by Rao and Ruekert (1994, p.89): "If one brand name on a product gives a certain signal of quality, then the presence of a second brand name on the product should result in a signal that is at least as powerful, if not more powerful, than the signal in the case of the single brand name". Signaling theory is found in, amongst others, in studies by Park et al. (1996), Simonin and Ruth (1998), and Singh et al. (2014).

Lastly, Attitude accessibility suggests that the stronger the attitude, the more easily it is accessed from memory, and in general, the stronger the attitude, the more familiar the person is with the attitude object (Fazio et al., 1989). According to the theory, transfer effect occurs when consumers' judgements are retrieved automatically and transferred to the evaluation of the co-branded product through confrontation with a sufficiently strong stimulus. As suggested by Lafferty and Goldsmith (2005): "When information exists where one attitude object is familiar, and the other is not as familiar, subjects anchor on information that is most easily accessible or the first thing that comes to mind and then adjust for the less salient 
information" (p. 424). Therefore, if the attitude towards Brand A is negative and the brand is familiar, consumers will focus on the negative attribute and adjust their attitudes toward Brand B and vice versa. Studies drawing on attitude accessibility to extend the study of brand alliances include Vaidyanatahan and Aggarwal (2000), Lafferty et al. (2004), and Helmig et al. (2007).

While the above theories offer valuable insight on the cognitive processing of co-branding, they do not account for attributes that might impact the weights assigned to co-branding, such as cognitive biases or individual characteristics. For example, Skowronski and Carlston (1989) suggest that when an individual is presented with good and bad stimuli, negativity dominance tends to cause an individual to evaluate negative information more strongly than positive ones. It is, therefore, likely that other factors other than congruence or recurring associations can explain how consumers reconcile their attitudes toward co-brand alliances. Future research could consider exploring such alternatives.

\section{Co-Branding in other Contexts}

The above review has focussed exclusively on the empirical outcomes of co-branding research in product-related categories in the Business-to-Consumer (B2C) and Business-to Business (B2B) markets. However, co-branding is also a popular marketing practice for organisations in non-product related contexts as well, such as in the services industry (e.g., Europcar and Easy Jet), sports domain (e.g., Chelsea and Besiktas football clubs) and the tourism sector (e.g., Euro-Mediterranean Partnership). In the discussion below, co-branding in other contexts such as cause-brand alliances, higher education and country co-marketing are discussed. 
An expanding area of research is cause-brand alliances or cause-related co-branding. Defined as a commercial activity by which an organisation builds a relationship with one or more causes for mutual benefit (Adkins, 2007), cause-related co-branding has become a buzzword in the marketing literature in recent times. Cause-brand alliances offer a range of benefits to the cause partners such as an increase in financial donations and enhanced social impact on society (Till and Nowark, 2000). By partnering with charitable causes, consumers' attitudes toward the brand are strengthened (Galan-Ladero, Galera Casquet and Singh, 2015).

Moreover, the partnership can lead to improved brand awareness, enhanced consumer trust, greater purchase intentions, higher profits and increased customer loyalty (e.g., Van den Brink, Odekerken-Schröder and Pauwels, 2006; Gupta and Pirsch, 2006; Youn and Kim, 2008; Krishna and Rajan, 2009).

To be an effective marketing strategy however, organisations must be clear that the objectives of the partnership are clear and that the fit between the brand and the cause is suitable. As suggested by Lichtenstein, Drumwright and Braig (2004), fit plays a pivotal role in consumer acceptance of the alliance. The authors show that consumers' attitudes toward cause-related alliances are favourable when the consumers' perceptions of the cause are similar to their perceptions of the brand. Interestingly, the assumption that fit will improve attitude towards the cause alliance has been challenged by Lafferty (2007) who demonstrate that the perceived fit between the cause and brand may not always affect consumers' acceptance of an alliance. The author contends that while the fit in some cause-brand alliances is appropriate and successful (Pampers and UNICEF), there are other partnerships that may not be compatible yet successfully achieve its objectives (M\&M Candies and The Susan Komen Breast Cancer Research Foundation). Overall, the literature positions cause-brand alliances as an effective strategy to increase an organisation's brand value despite the lack of consensus regarding the 
implications of fit. Further research can examine how and under what conditions fit influences consumers' evaluations of cause-brand alliances.

In addition to cause-brand alliances, country co-branding represents another context that has received increasing attention from academics. There is a small but growing body of literature pertaining to co-branding that offers valuable insights on the prominence of a country and its impact on a partnered national brand (e.g., Papadopoulous and Heslop, 2002; Bluemelhuber et al., 2007). These studies show that the image effects of a country can have a significant impact for organisations wishing to position itself in a new market. As suggested by Motion, Leitch and Brodie (2003), companies pursuing an alliance with a national entity can successfully redefine its identity and build brand equity.

Another non-product context is the alliance between institutions in the higher education sector. Joint degree partnerships between educational institutes are increasingly popular due to the increased demand from universities seeking to deliver innovative and quality programs that differentiate itself across international borders (Papatsiba, 2014). In the first brand alliance study in higher education sector, Kalafatis et al. (2016) examine the perceptions of co-branding in the form of dual degrees, between UK Universities. The authors demonstrate that the perceptions of added value of a dual degree initiated by a high(low) ranked context university decline (increase) in line with the ranking of a lower (higher) rank partner university. The findings reveal interaction effects between the rank position of the initiating university and the evaluation criteria. Name-order effects explain the higher perceived value of a dual degree between high-and-low ranked universities compared to a dual degree between low-and-high ranked universities. 


\section{Conclusions}

The present chapter reviews the extant co-branding literature. The discussion in the preceding sections shows that further research is merited to reveal the benefits as well as pitfalls of this increasingly popular strategy. The chapter concludes by identifying avenues for further research in the co-branding domain.

The first issue that merits research is the comparative account of co-branding successes and failures. While there is evidence to suggest that co-branding can aid an unknown brand gain access to a new market, enhance CBBE and minimise start-up costs, there is no empirical evidence so far to support the assertion that co-branding is also an effective strategy for delivering quicker returns, price premiums, enhanced distribution and technical capabilities. Further research could confirm whether co-branding can achieve these benefits. The studies supporting the advantages of co-branding have only explored these over a short-term in cross-sectional studies where data were collected at a single point in time. While short-term evaluations are a start, longitudinal measurements (e.g., a field setting using scanner panel data) are required to provide much-needed evidence on the enduring impact of this strategy on consumers' evaluations of co-brands over time.

Furthermore, current literature has focussed predominately on the benefits of co-branding. The literature suggests that risks can occur in brand alliances when an unexpected brand event undermines consumers' perceptions of the host brand. However, there is no evidence of its consequences on the organisations' short or long-term financial performance. Further, there is no empirical study examining whether a brand partner's transgression is likely to transfer to the co-branded product. Future co-branding research should ascertain whether 
negative events that affect one partner brand will spill over on consumers' subsequent evaluations of the co-brand.

Another area that deserves research attention is the impact of co-branding in the luxury context, specifically relating to 'masstige' dual alliances. Masstige, a term used to describe an alliance between a prestigious luxury brand and a consumer brand (Troung, McColl and Kitchen, 2009), is a common practice for brands across several product categories such as cosmetics and fashion. Examples include Balmain and H\&M, Karl Lagerfeld and Coca-Cola, Sephora and Bath and Body Works, Mossimo and Target. In this regard in a conceptual paper, Oeppen and Jamal (2014) highlight the multiple drivers for alliances between luxury and mass market brands. Further research can empirically examine the effectiveness of the conditions for co-branding success discussed in the previous sections (e.g., fit and familiarity) in the masstige context. Knowledge in this area would highlight the challenges and risks that can occur in masstige alliances, particularly for the luxury brand whose core appeal is less visibility. Other suggestions for future research may focus on the effects of masstige strategies over time to determine whether the value of the alliance is a good indicator of longterm brand value for both brands (Paul, 2015).

A further issue in the co-branding domain that warrants future consideration relates to online alliances. Although research in co-branding continues to evolve in the offline space, alliances in the online context have yet to receive attention. This is surprising, given the acceleration of digital alliances (e.g., Spotify and Starbucks, Orbitz and the European Travel Commission). In an era where the boundaries between online and offline are blurring, knowledge and understanding of how organisations can successfully navigate digital co-branding to achieve competitive advantage are warranted. 


\section{References}

Aaker, D. (1991), Managing brand equity: capitalizing on the value of a brand name, New York: Free Press.

Aaker, D. (2004), Brand portfolio strategy: creating relevance, differentiation, energy, leverage, and clarity, New York: Free Press.

): Abratt, R. and Motlana, P. (2000), "Managing co-branding strategies: global brands into local markets”, Business Horizons, 45(5): 43-50.

Adkins, S. (2007), Cause-related marketing, Routledge.

Ahluwalia, R., Burnkrant, R. and Unnava, H. (2000), "Consumer response to negative publicity: the moderating role of commitment", Journal of Marketing Research, 37 (2), pp. 203-14.

Allen, M. and Burrell, N. (2002), “The negativity effect in political advertising. A metaanalysis", In J.P. Dillard and M. Pau (Eds), The persuasion handbook: developments in theory and practice. Californian: Sage Publications, pp. 83-96

Allen, B. and Hamilton (1998), Institutionalizing alliance skills: secrets of repeatable success, Booz Allen \& Hamilton: USA.

Anderson, N. (1981), Foundations of information integration theory, New York: Academic Press.

Anderson, J. (1983), “A spreading activation theory of memory”, Journal of Verbal Learning and Verbal Behaviour, 22(3): 261-295.

Austin, J. E. (2000), "Strategic collaboration between non-profits and business", Non-profit and Voluntary Sector Quarterly, 29(1): 69-97. 
Balachander, S. and Ghose, S. (2003), "Reciprocal spill over effects: a strategic benefit of brand extensions", Journal of Marketing, 67(1): 4-13.

Baumeister, R., Bratslavsky, E., Finkenauer, C. and Vohs, K. (2001), "Bad is stronger than good", Review of General Psychology, 5(4): 323-370.

Baumgarth, C. (2004), "Evaluations of co-brands and spill-over effects: Further empirical results", Journal of Marketing Communications, 10(2): 115-131.

Bengtsson, A. and Servais, P. (2005), "Co-branding on industrial markets”, Industrial Marketing Management, 34(7): 706-713.

Besharat, A. (2010), "How co-branding versus brand extensions drive consumers' evaluations of new products: a brand equity approach", Industrial Marketing Management, 39(8): 12401249.

Besharat, A. and Langan, R. (2014), "Towards the formation of consensus in the domain of co-branding: current findings and future priorities", Journal of Brand Management, 21(2): $112-132$.

Blackett, T. and Boad, B. (1999), Co-branding: the science of alliance, London: Palgrave Macmillan.

Bluemelhuber, C., and Lambe, J. (2007), "Extending the view of brand alliance effects: an integrative examination of the role of country of origin", International Marketing Review, 24 (4): 427- 443.

Bouten, L. M., Snelders, D. and Hultink, E. J. (2011), “The impact of fit measures on the consumer evaluation of new co-branded products", Journal of Product Innovation Management, 28(4): 455-469.

Bucklin, L. P. and Sengupta, S. (1993), “Organising successful co-marketing alliances”, The Journal of Marketing, 57 (2): 32-46. 
Cooke, S. and Ryan, P. (2000), "Brand alliances: from reputation endorsement to collaboration on core competencies", Irish Marketing Review, 13(2): 36-42.

Das, T. K. and Teng, B. S. (1998), "Resource and risk management in the strategic alliance making process", Journal of Management, 24(1): 21-42.

Day, G. S. (1995), “Advantageous alliances”, Journal of the Academy of Marketing Science, 23(4): 297-300.

Desai, K. and Keller, K. (2002), "The effects of ingredient branding strategies on host brand extendibility", Journal of Marketing, 66(1): 73-93.

Erevelles, S., Stevenson, T., Srinivasan, S. and Fukawa, N. (2008), “An analysis of B2B ingredient co-branding relationships", Industrial Marketing Management, 37(1): 940-952. Fazio, R., Powell, M. and Williams, C. (1989), "The role of attitude accessibility in the attitude-behaviour process", Journal of Consumer Research, 16(3): 280-288.

Fiske, S. (1980), "Attention and weight in person perception: the impact of negative and extreme behaviour ", Journal of Personality and Social Psychology, 38(6): 889-906. Fullerton, G. (2003), “When does commitment lead to loyalty?” Journal of service research, 5(4): 333-344.

Gammoh, B., Voss, K. and Chakraborty, G. (2006), "Consumer evaluation of brand alliance signals", Psychology \& Marketing, 23(6): 465-486.

Galan-Ladero, M., Galera Casquet, C. and Singh, J. (2015), "Understanding factors influencing consumer attitudes toward cause-related marketing", International Journal of Non-profit and Voluntary Sector Marketing, 20(1): 52-70.

Guillet, B. D. and Tasci, A. D. (2010), “An exploratory study of multi-cultural views on the Disney-McDonald's alliance", Journal of Travel \& Tourism Marketing, 27(1): 82-95. Gupta, S. and Pirsch, J. (2006),"The company-cause-customer fit decision in cause-related marketing", Journal of Consumer Marketing, 23(6): 314 - 326. 
Helmig, B., Huber, J. and Leeflang, P. (2007), "Explaining behavioural intentions toward cobranded products", Journal of Marketing Management, 23(3-4): 285-304.

Helmig, B., Huber, J. and Leeflang, P. (2008), “Co-branding: the state-of-the-art”, Schmalenbach Business Review, 60, pp. 359-377.

Ito, T., Larsen, J., Smith, N. and Cacioppo, J. (1998), "Negative information weighs more heavily on the brain: the negativity bias in evaluative categorizations", Journal of Personality and Social Psychology, 75(4): 887-900.

James, D. (2005), "Guilty through association: brand association transfer to brand alliances", Journal of Consumer Marketing, 22 (1): 14-24.

Kanter, R. M. (1994), “Collaborative advantage”, Harvard Business Review, 72(4): 96-108. Kalafatis, S.P., Remizova, N., Riley, D. and Singh, J. (2012), “The differential impact of brand equity on B2B co-branding", Journal of Business \& Industrial Marketing, 27(8): 623634

Kalafatis, S.P., Riley, D. and Singh, J. (2014), “Context effects in the evaluation of businessto-business brand alliances", Industrial Marketing Management, 43(2): 322-334.

Kalafatis, S. P., Ledden, L., Riley, D. and Singh, J. (2016), "The added value of brand alliances in higher education", Journal of Business Research (forthcoming). Krishna, A. and Rajan, U. (2009), "Cause marketing: spill over effects of cause-related products in a product portfolio", Management Science, 55(9): 1469-1485.

Kumar, P. (2005), "The impact of co-branding on customer evaluation of brand counter extensions", Journal of Marketing, 69(3): 1-19.

Lafferty, B. A. (2007), “The relevance of fit in a cause-brand alliance when consumers evaluate corporate credibility", Journal of Business Research, 60(5): 447-453.

Lafferty, B., Goldsmith, R. and Hult, G. (2004), “The impact of the alliance on the partners: A look at cause-brand alliances”, Psychology and Marketing, 21(7): 509-31. 
Lafferty, B. and Goldsmith, R. (2005), “Cause-brand alliances: does the cause help the brand or does the brand help the cause?" Journal of Business Research, 58(4): 423-429

Lambe, C. J., Spekman, R. E. and Hunt, S. D. (2002), “Alliance competence, resources, and alliance success: conceptualization, measurement, and initial test", Journal of the Academy of Marketing Science, 30(2): 141-158.

Lanseng, E. and Olsen, L. (2012), "Brand alliances: the role of brand concept consistency”, European Journal of Marketing, 46(9): 1108-1126.

Lebar, E., Buehler, P., Keller, K. L., Sawicka, M., Aksehirli, Z. and Richey, K. (2005), "Brand equity implications of joint branding programs", Journal of Advertising Research, 45(04): 413-425.

Leuthesser, L., Kohli, C. and Suri, R. (2003), " $2+2=5$ ? A framework for using co-branding to leverage a brand", Journal of Brand Management, 11(1): 35-47.

Levin, A., Davis, J. and Levin, I. (1996), “Theoretical and empirical linkages between consumers "e responses to different branding strategies", in K. Corfman and J. Lynch (Eds.), Advances in Consumer Research, Association for Consumer Research, Provo, UT, 23, pp. 296-300

Lichtenstein, D. R., Drumwright, M. E. and Braig, B. M. (2004), "The effect of corporate social responsibility on customer donations to corporate-supported non-profits", Journal of Marketing, 68 (4): 16-32.

Mazodier, M. and Merunka, D. (2012), “Achieving brand loyalty through sponsorship: the role of fit and self-congruity", Journal of the Academy of Marketing Science, 40(6): 807-820. Musante, M. (2000), The impact of brand alliances on brand image and favourability perceptions, Ph. D thesis, University of Massachusetts Amherst. Nguyen, V. and Claus, E. (2013), “Good news, bad news, consumer sentiment and consumption behaviour", Journal of Economic Psychology, 39, pp. 426-438. 
Oeppen, J. and Jamal, A. (2014), “Collaborating for success: managerial perspectives on cobranding strategies in the fashion industry", Journal of Marketing Management, 30(9-10): 925-948.

Oliver, R. L. (1999), “Whence consumer loyalty?” Journal of Marketing, 63 (4): 33-44.

Park, C, Jun, S. and Shocker, A. (1996), "Composite branding alliances: an investigation of extension and feedback effects", Journal of Marketing Research, 33(4): 453-66.

Papadopoulos, N. and Heslop, L. (2002), “Country equity and country branding: problems and prospects", Journal of Brand Management, 9(4): 294-314.

Papatsiba, V. (2014), "Policy goals of european integration and competitiveness in academic collaborations: an examination of joint master's and erasmus mundus programmes", Higher Education Policy, 27(1): 43-64.

Paul, J. (2015), "Masstige marketing redefined and mapped: introducing a pyramid model and MMS measure", Marketing Intelligence \& Planning, 33(5): 691-706.

Rao, A. and Ruekert, R. (1994), "Brand Alliances as signals of product quality”, Sloan Management Review, 36(1): 87-97.

Report Buyer (2014), Co-Branded and affinity credit cards in the U.S., 4th Edn. Rodrigue, C. and Biswas, A. (2004), "Brand alliance dependency and exclusivity: an empirical investigation”. Journal of Product \& Brand Management, 13(7): 477-487. Samu, S., Krishnan, H. and Smith, R. (1999), "Using advertising alliances for new product introduction: interactions between product complementarity and promotional strategies", Journal of Marketing, 63 (1): 57-74.

Simonin, B. and Ruth, J. (1998), "Is a company known by the company it keeps? Assessing the spill over effects of brand alliances on consumer brand attitudes", Journal of Marketing Research, 35(1): 30-42. 
Singh, J. (2015), “The Influence of CSR and ethical self-identity in consumer evaluation of co-brands", Journal of Business Ethics (e-pub). DOI: 10.1007/s10551-015-2594-4.

Singh, J., Kalafatis, S.P. and Ledden, L. (2014), "Consumer perceptions of co-brands: the role of brand positioning strategies”, Marketing Intelligence \& Planning, 32(2): 145-159. Spence, M. (1973), “Job market signalling”, Quarterly Journal of Economics, 87 (3): 355374.

Skowronski, J. and Carlston, D. (1989), "Negativity and extremity biases in impression formation: a review of explanations", Psychological Bulletin, 105 (1): 131-42.

Suh, J. and Park, S. (2009), "Successful brand alliance and its negative spill over effect on a host brand: test of cognitive response hypothesis", Advances in Consumer Research, 36, pp. 243-247.

Swaminathan, V., Reddy, S. and Dommer, S. (2012), "Spillover effects of ingredient branded strategies on brand choice: a field study", Marketing Letters, 23(1): 237-251.

Till, B. D. and Nowak, L. I. (2000), “Toward effective use of cause-related marketing alliances", Journal of Product \& Brand Management, 9(7): 472-484.

Till, B. and Shimp, T. (1998), "Endorsers in advertising: the case of negative celebrity information", Journal of Advertising, 27(1): 67-82.

Truong, Y., McColl, R. and Kitchen, P. J. (2009), "New luxury brand positioning and the emergence of masstige brands", Journal of Brand Management, 16(5): 375-382.

Ueltschy, L. and Laroche, M. (2011), “Co-Branding internationally: everyone wins?” Journal of Applied Business Research, 20(3): 91-102.

Vaidyanathan, R. and Aggarwal, P. (2000), "Strategic brand alliances: implications of ingredient branding for national and private label brands", Journal of Product \& Brand Management, 9(4): 214-228. 
Van Osselaer, S. M. and Alba, J. W. (2000), "Consumer learning and brand equity”, Journal of Consumer Research, 27(1): 1-16.

Van den Brink, D., Odekerken-Schröder, G. and Pauwels, P. (2006), "The effect of strategic and tactical cause-related marketing on consumers' brand loyalty”, Journal of Consumer Marketing, 23(1): 15-25.

Varadarajan, P. (1986), "Horizontal cooperative sales promotion: a framework for classification and additional perspectives", Journal of Marketing, 50(2): 61-73.

Voss, K. and Gammoh, B. (2004), "Building brands through brand alliances: does a second ally help?" Marketing Letters, 15(2-3): 147-159.

Votolato, N. and Unnava, H. (2006), "Spill over of negative information on brand alliances", Journal of Consumer Psychology, 16(2): 196-202.

Washburn, J., Till, B. and Priluck, R. (2000), "Co-branding: brand equity and trail effects", Journal of Consumer Marketing, 17(6/7): 591-604.

Washburn, J., Till, B. and Priluck, R. (2004), "Brand alliances and customer-based brandequity effects", Psychology and Marketing, 21(7): 487-508.

Weber, K. and Sparks, B. (2004), “Consumer attributions and behavioural responses to service failures in strategic airline alliance settings", Journal of Air Transport Management, 10(5): 361-367.

Yadav, M. S. and Monroe, K. B. (1993), "How buyers perceive savings in a bundle price: an examination of a bundle's transaction value", Journal of Marketing Research, 30(3): 350358.

Youn, S. and Kim, H. (2008), “Antecedents of consumer attitudes toward cause-related marketing”, Journal of Advertising Research, 48 (1), pp 123-137 